\title{
Improving Baking Quality of Weak Gluten Semolina Using Ovine Whey Powder
}

\author{
Nicola Secchi, ${ }^{1,2}$ Costantino Fadda $\left(\mathbb{D},{ }^{2}\right.$ Ivo Pinna, ${ }^{1}$ Alessandra Del Caro $\left(\mathbb{D},{ }^{2}\right.$ Paola Conte, ${ }^{2}$ \\ Antonio Piga, ${ }^{2}$ Simonetta Fois, ${ }^{1}$ and Pasquale Catzeddu ${ }^{1}$ \\ ${ }^{1}$ Porto Conte Ricerche Srl, Località Tramariglio, 07041 Alghero, Italy \\ ${ }^{2}$ Dipartimento di Agraria, Università degli Studi di Sassari, Viale Italia 39/A, 07100 Sassari, Italy
}

Correspondence should be addressed to Alessandra Del Caro; delcaro@uniss.it

Received 26 January 2018; Accepted 29 March 2018; Published 8 May 2018

Academic Editor: Marina Carcea

Copyright (C) 2018 Nicola Secchi et al. This is an open access article distributed under the Creative Commons Attribution License, which permits unrestricted use, distribution, and reproduction in any medium, provided the original work is properly cited.

The effect of the addition of ovine whey powder at 5\%,10\%, and $15 \%$ on bread quality was studied. Two different types of semolina were used, one being a commercial blend with strong and tenacious gluten (48T) and the other coming from one single cultivar, characterized for having weak and sticky gluten (4T). Two different types of typical Mediterranean bread were produced, pan bread and flat bread, and their quality characteristics were measured, together with their shelf life. The volume of $4 \mathrm{~T}$ pan bread was improved by the addition of $5 \%$ ovine whey powder. In the case of $48 \mathrm{~T}$, the volume of bread was negatively affected by the addition of ovine whey powder. Moreover, flat bread made with $4 \mathrm{~T}$ was more extensible after the addition of ovine whey powder and showed lower starch retrogradation over time than the same type of bread made with 48T. Among the different pan bread types, consumers preferred $4 \mathrm{~T}$ with $5 \%$ of substitution, which also showed an improved cell size distribution in the crumb.

\section{Introduction}

Durum wheat is used worldwide to make dry pasta, and for this reason durum wheat breeding programs have been focused on improving pasta cooking quality, through improving gluten strength, rather than bread-making quality [1]. Bread quality is determined by an appropriate balance between dough viscosity and elasticity [2]. Old varieties show poor adaptability for the employment in modern bakery plants, due to their low protein quality. In fact, the old genotypes often showed HMG-20 glutenin patterns, which are well recognized as markers for gluten weakness in durum wheat. In addition, these old genotypes may present the $\gamma$-gliadin 42 type, which is a marker for the LMW2 glutenin pattern, also related to weak gluten characteristics.

Whey, a by-product of the dairy industry, represents a potential source of low cost functional proteins that have emulsifying, foaming, and gelling properties [3]. The major whey proteins, primarily $\beta$-lactoglobulin and secondarily $\alpha$ lactalbumin, represent a well-balanced source of essential amino acids, thus having a significant meaning as nutritional ingredients [4]. Nevertheless, whey proteins are known to exert negative effects on bread quality, by depressing loaf volume and increasing crumb firmness, although after denaturation this effect seems to disappear $[5,6]$. Generally, as reported by Erdogdu-Arnoczky et al. [5], the effect of the addition of whey powder in the dough varies depending on the technological conditions of the whey powder production, the quality of the flour, and the technological parameters of baking. This research focuses on the effect of ovine whey powder (OWP) added at different percentages on the baking quality of semolina. This effect was studied on two types of bread, a conventional pan bread and a leavened Mediterranean flat bread (Spianata). Bread was prepared using two types of semolina: one is a commercial blend with strong gluten and the second one is obtained from an old variety (Senatore Cappelli) and characterized by a low quality. Quality of fresh bread was evaluated and staling during storage was monitored by means of texture analysis and Raman spectroscopy, to evaluate in depth the evolution of starch crystallinity over time. Sensory analyses 
were performed on pan bread with the aim of verifying the consumer acceptability.

\section{Materials and Methods}

2.1. Bread-Making Process. A commercial OWP with $15 \%$ of protein was used (Alimenta Srl, Sardinia, Italy) and mixed with the semolina at increasing percentages of substitution $(0,5,10$, and $15 \% \mathrm{w} / \mathrm{w})$ to make both pan bread and double layered and leavened flat bread (Spianata). Eight breadmaking trials were carried out in a semiautomated bakery plant at Porto Conte Ricerche Srl (Alghero, Sardinia, Italy). Bread samples were coded using the names of the semolina sample (48T or $4 \mathrm{~T}$ ) followed by either the OWP percentage or $\mathrm{C}$ for control samples. Protein $(\% \mathrm{~N} \times 5.7)$, calculated on dry basis, and particle size distribution of semolina samples were analyzed using the AACC Approved Method 46-12 and 66-20, respectively [7]. The $4 \mathrm{~T}$ semolina was obtained by industrial milling of the Senatore Cappelli cultivar, while the $48 \mathrm{~T}$ semolina was a blend of durum wheat cultivars that are commonly used to make pasta and semolinabased bread. Particle size distribution of the two semolina samples was similar: the fraction $>300 \mu \mathrm{m}$ accounted for $0.6 \%$, the fraction between 300 and $180 \mu \mathrm{m}$ accounted for about $47 \%$, and the fraction $<180 \mu \mathrm{m}$ accounted for about $53 \%$ of the total. Following the AACC Approved Method 54-50 [7], a consistograph (Chopin, France) was used to determine water absorption capacity at a consistency of 2.200 mbar (hydration\%, 15\%, moisture basis), as well as the time required to reach this consistency (TPrMAX, s) and the mixing time (the time needed to reach $75 \%$ of the maximum pressure, min). Ingredients and formulations are reported in Table 1. A total of $17 \mathrm{~kg}$ of dough for each sample was prepared in a fork mixer. The water content of dough was calculated on the basis of consistographic HYDHA values, as previously reported by Secchi et al. [8], and salt percentage was $2.5 \%$ of water content [7]. The amount of baker's yeast consisted of $1.0 \%$ of the total weight of semolina plus OWP. The mixing time was calculated as described by Vinci et al. [9]. After mixing, the first proofing was conducted in a fermentation chamber set at $28^{\circ} \mathrm{C}$ and $80 \%$ relative humidity (RH) for $35 \mathrm{~min}$. Then, to produce pan bread, six pieces of dough $(1.2 \mathrm{~kg}$ for each piece) were introduced in aluminium pans and kept in the fermentation chamber $\left(28^{\circ} \mathrm{C}\right.$ and $80 \%$ $\mathrm{RH})$ for $120 \mathrm{~min}$ before baking at $230^{\circ} \mathrm{C}$ for $35 \mathrm{~min}$. Then, the bread was set aside for cooling at room temperature for 4 h.

To produce Spianata bread, the remaining dough ( $9 \mathrm{~kg}$ ) was divided into three pieces, which were mechanically sheeted (Manomat 2000, Rondo Srl, Schio, Italy) with an initial gap of $25 \mathrm{~mm}$. Each dough was sheeted 9 times, progressively reducing the gap between the rollers until a thickness of $1.5 \mathrm{~mm}$ was reached. Then, the sheeted dough was shaped using a $22 \mathrm{~cm}$ diameter circular mould, placed in an aluminium tray, and covered with cotton fabric. The second proofing was conducted for $90 \mathrm{~min}$, under the same fermentation conditions as the pan bread. The dough leaves were baked in a tunnel oven at $480^{\circ} \mathrm{C}$ for $20-30 \mathrm{~s}$ taking care not to burn them. Then, the bread was set aside for cooling at
TABLE 1: Formulation of doughs prepared with low grade semolina (4T and $48 \mathrm{~T})$ and different percentages of OWP.

\begin{tabular}{lcccc}
\hline Samples & Semolina $(\%)^{*}$ & OWP $(\%)$ & Water $(\%)$ & Salt $(\%)$ \\
\hline 4TC & 67.25 & 0.00 & 31.93 & 0.82 \\
4T5 & 65.57 & 3.45 & 30.21 & 0.77 \\
4T10 & 63.60 & 7.07 & 28.60 & 0.73 \\
4T15 & 61.33 & 10.82 & 27.15 & 0.70 \\
48TC & 67.79 & 0.00 & 31.41 & 0.81 \\
48T5 & 65.82 & 3.50 & 29.94 & 0.77 \\
48T10 & 64.05 & 7.10 & 28.11 & 0.72 \\
48T15 & 61.28 & 10.80 & 27.21 & 0.70 \\
\hline
\end{tabular}

${ }^{*} \%$ on dough weight basis.

room temperature for $4 \mathrm{~h}$, packaged ( 3 bread loaves per bag), and stored (at the same conditions as pan bread) to avoid moisture changes during storage due to dehydration. Stored samples were used for textural analyses. The experiment was repeated twice.

2.2. Volume and Browning Index of Pan Bread. Bread volume was measured using the seed displacement method [8]. Loaves were cut into $2 \mathrm{~cm}$ thick slices, and the 3 central slices were packaged individually using a water vapour and oxygen high barrier plastic film (oxygen transmission rates were $4 \mathrm{~cm}^{3} \mathrm{~m}^{-2} 24 \mathrm{~h}^{-1}$ bar $^{-1}$ at $23^{\circ} \mathrm{C}$; water vapour transmission rates were $9 \mathrm{~g} \mathrm{~m}^{-2} 24 \mathrm{~h}^{-1}$ at $38^{\circ} \mathrm{C}$ ) to avoid moisture changes during storage. A sachet of oxygen absorber (Freshcare, $\mathrm{O}_{2}$ Control, Netherlands) was placed inside the bags to avoid mould development. The slices were stored under controlled conditions $\left(20 \pm 0.5^{\circ} \mathrm{C}\right)$, for texture analyses. The experiment was repeated twice. Browning index was determined on the crust of the pan bread samples, using a CM-700d spectrophotometer (Konica Minolta Sensing, Inc., Osaka, Japan) with a D65 illuminant and a $10^{\circ} \mathrm{CIE}$ standard observer angle. $L^{*}$ (lightness), $a^{*}$ (redness), and $b^{*}$ (yellowness) coordinates were obtained. Before each measurement, the spectrophotometer was calibrated against the white tile supplied with the instrument. Measurements were taken after 1 day of storage and readings were performed on 3 different points of each sample.

\subsection{Texture Analysis of Dough and Bread. A TA.XT2i Texture} Analyzer (Stable Micro System Ltd., Godalming, Surrey, UK) equipped with a $30 \mathrm{~kg}$ load cell was used to perform the texture analyses on dough and bread. Dough was mixed to its optimum mixing time, as described by Vinci et al. [9], which corresponded to a consistency of $\sim 1600 \mathrm{mb}$ at the consistograph. At this point, the dough was subjected to a compression test at $10 \%$ strain with a $\mathrm{P} / 50$ probe (pretest, test and posttest speeds were $2.0,1.0$, and $10.0 \mathrm{~mm} / \mathrm{s}$, resp.) and maximum force was recorded. The value of the maximum force was the same for all the doughs $(3.8 \pm 0.3 \mathrm{~N})$, as expected, as they were mixed to the same consistency. This value was used as a reference value for the dough obtained with the fork mixer. As soon as the dough started to develop in the fork mixer, samples of dough (30 g) were collected at intervals 
of 1 minute for texture analysis. These samples were sheeted and formed into $45 \mathrm{~mm}$ diameter discs, with the Alveograph (Model Alveographe NG, Chopin, France) equipment, and submitted to the compression test. Once the reference value of $3.8 \pm 0.3 \mathrm{~N}$ was reached, the mixing phase was stopped.

Stress relaxation tests were carried out on the pan bread slices, to monitor the crumb hardening at $0,1,2,3$, and 6 days of storage. Six bread slices randomly selected were analyzed each time. The crust was removed and samples were compressed for $40 \mathrm{~s}$ using an aluminium probe $\mathrm{P} 36 \mathrm{R}$ with a $10 \%$ strain, and the change in force $(\mathrm{N})$ versus time (s) was measured. A pretest speed of $2.0 \mathrm{~mm} / \mathrm{s}$, test speed of $1.0 \mathrm{~mm} / \mathrm{s}$, and a posttest speed of $10.0 \mathrm{~mm} / \mathrm{s}$ were used. Force versus time plots were recorded and a Maxwell model was used to elaborate the data [10]. For each sample, the maximum force value $(F \max , \mathrm{N})$ was detected and compared with the hardness perceived during sensory analysis.

A biaxial extensibility test was performed on Spianata bread to evaluate texture changes during storage. The test was carried out using a ball probe and the Tortillas/Pastry Burst Rig (HDP/TPD) platform. The parameters set on the instrument were as follows: pretest, $2.0 \mathrm{~mm} / \mathrm{s}$; test, $1.0 \mathrm{~mm} / \mathrm{s}$; posttest, $10.0 \mathrm{~mm} / \mathrm{s}$; and distance of penetration, $35 \mathrm{~mm}$. Distance-to-break $(\mathrm{mm})$ parameter was measured. Analyses were carried out at $0,1,2,3,6$, and 10 days. Six bread samples randomly selected were analyzed.

2.4. NIR FT-Raman Spectroscopy. NIR FT-Raman analyses were performed on both pan bread crumb and Spianata bread in order to study staling. A back-scattering geometry with a Bruker RAM II FT-Raman module coupled to a Bruker Vertex 70v interferometer was used. The instrument settings and the data analyses were done according to Piccinini [11]. Spectrum of OWP was subtracted from the spectra of the bread before spectra manipulation. This technique allows monitoring the retrogradation of starch over time, which is a significant factor in the determination of the textural changes that bread crumb undergoes during aging [12].

2.5. Bread Image Analysis. Cell size distribution was studied on the pan bread crumb, as previously reported by Fois et al. [13]. Images of 6 slices of pan bread for each sample were recorded $4 \mathrm{~h}$ after baking, using an Epson scanner (Expression 10000XL, Seiko Epson Corporation, Japan) supported by EpsonScan software, version 3.04E. An image in 24-bit colour at a resolution of 400 dots per inch, that is, 1 pixel $=$ $(60)^{2} \mu \mathrm{m}^{2}$, for each slice of pan bread was obtained. Image analysis was performed using the Sigma Scan Pro 5.0 software (Systat Software, Inc., USA). The images were pretreated by conversion into an 8-bit monochrome image. A threshold method was used for conversion to a binary image to optimize the image analysis. For each image, a square $(50 \mathrm{~mm} \times$ $50 \mathrm{~mm}$ ) in the top half of the pan bread slice was selected. The number of gas cells and the area $\left(\mathrm{mm}^{2}\right)$ of each gas cell were determined. The cell size distribution was modeled by a log-normal distribution across the full range of cell areas, which ranged from $10^{-3}$ to $10^{1} \mathrm{~mm}^{2}$. Table Curve 2.D v.5.01
(Systat Software Inc., San José, California, USA) was used to process data. The percent explained variation $\left(R^{2}\right)$ was $>0.96$.

2.6. Sensory Analysis. CATA test (Check All That Apply) was applied on the eight pan bread samples. After cooling, bread was cut into slices of $20 \mathrm{~mm}$ thickness and stored frozen until the day of evaluation. One hour before the sensory session, samples were thawed and 8 different slices were presented to the consumers, one after another at 5-minute intervals. The order of presentation of pan bread samples was randomized and balanced [14] between participants, and the order of the attributes within the CATA list was appropriately balanced and randomized within participants [15]. In addition, consumers judged the overall liking and propensity to purchase bread, using a 9-point scale [16] with the aim of relating CATA results to consumer acceptance. The panel was composed of 56 consumers ( $57 \%$ male, $43 \%$ female). Each consumer evaluated all the bread samples using a CATA list containing 18 attributes, most of them already used in the literature for bread sensory evaluation [17]. The consumers were asked to select only the attributes they considered appropriate. The 18 attributes used were the following: sticky, good to accompany, smell of dairy products, very good for diet, unpleasant smell, salty, dry, soft, nice colour, soft to touch, healthy, innovative product, sweet, springy to touch, good for nutrition, smell of traditional bread, rubbery, and ideal for breakfast. Consumers were provided with water as palate cleansers between samples.

2.7. Statistical Analysis. Data were analyzed by analysis of variance (ANOVA), and Duncan's multiple range test ( $p \leq$ $0.05)$ was used to separate means.

Data obtained from CATA test were analyzed using Cochran's $Q$ test $(p<0.05)$ to evaluate the significant differences among samples for each of the attributes used. Correspondence analysis (CA) was performed to obtain a sensory map among samples and CATA attributes. One-way analysis of variance (ANOVA) was carried out on data of overall liking and purchase intention attributes to evaluate significant differences among samples. Pearson's correlation coefficient between chemical and texture parameters and sensory attributes, where pertinent, was calculated. Data were processed with the software XLSTAT.

\section{Results and Discussion}

3.1. Properties of Dough and Bread. Mixing times and hydration values of the different dough formulations are reported in Table 2. The addition of OWP significantly affected the time required to mix all the experimental bread samples as well as the time to reach the maximum consistency in the consistographic analysis (TPrMax). This effect was more prominent at increasing percentages of addition. The increase of the mixing times suggested that the addition of OWP made the formation of the gluten network in the dough more difficult, as already reported by other authors $[18,19]$.

Pan bread volumes are reported in Figure 1. As expected, the volume of the $4 \mathrm{TC}$ was significantly lower than that of 
TABLE 2: Properties of dough samples.

\begin{tabular}{lcccc}
\hline Sample & $\begin{array}{c}\text { Mixing time } \\
(\min )\end{array}$ & $\begin{array}{c}\text { Hydration }^{*} \\
\left(\% 15 \% \mathrm{mb}^{1}\right)\end{array}$ & $\begin{array}{c}\text { TPrMAX }^{*} \\
(\mathrm{~s})\end{array}$ & $\begin{array}{c}\text { Protein content } \\
\left(\% \mathrm{db}^{2}\right)\end{array}$ \\
\hline 4T C & $17^{\mathrm{e}}$ & $50.3^{\mathrm{a}}$ & $110.5^{\mathrm{d}}$ & $11.07^{\mathrm{e}}$ \\
4 T 5 & $20^{\mathrm{d}}$ & $45.0^{\mathrm{c}}$ & $147.5^{\mathrm{cd}}$ & $11.65^{\mathrm{d}}$ \\
4 T 10 & $23^{\mathrm{c}}$ & $39.9^{\mathrm{e}}$ & $234.5^{\mathrm{bc}}$ & $12.10^{\mathrm{cd}}$ \\
4 T 15 & $30^{\mathrm{b}}$ & $36.8^{\mathrm{g}}$ & $334.5^{\mathrm{ab}}$ & $12.72^{\mathrm{b}}$ \\
$48 \mathrm{~T} \mathrm{C}$ & $21^{\mathrm{d}}$ & $48.5^{\mathrm{b}}$ & $150.0^{\mathrm{cd}}$ & $12.86^{\mathrm{b}}$ \\
$48 \mathrm{~T} \mathrm{5}$ & $27^{\mathrm{b}}$ & $44.2^{\mathrm{d}}$ & $218.5^{\mathrm{c}}$ & $12.53^{\mathrm{bc}}$ \\
48 T 10 & $35^{\mathrm{a}}$ & $39.3^{\mathrm{f}}$ & $398.0^{\mathrm{a}}$ & $12.97^{\mathrm{ab}}$ \\
$48 \mathrm{~T} \mathrm{15}$ & $38^{\mathrm{a}}$ & $36.1^{\mathrm{h}}$ & $381.5^{\mathrm{a}}$ & $13.72^{\mathrm{a}}$ \\
\hline
\end{tabular}

Samples with different letters are significantly different at $p<0.05$ according to Duncan's multiple range test. ${ }^{*}$ TPrMAX: time to reach the maximum pressure in consistographic analysis. Hydration values (HYDHA) were from Secchi et al. (2017). ${ }^{1} \mathrm{mb}$ : moisture basis; ${ }^{2} \mathrm{db}$ : dry basis.

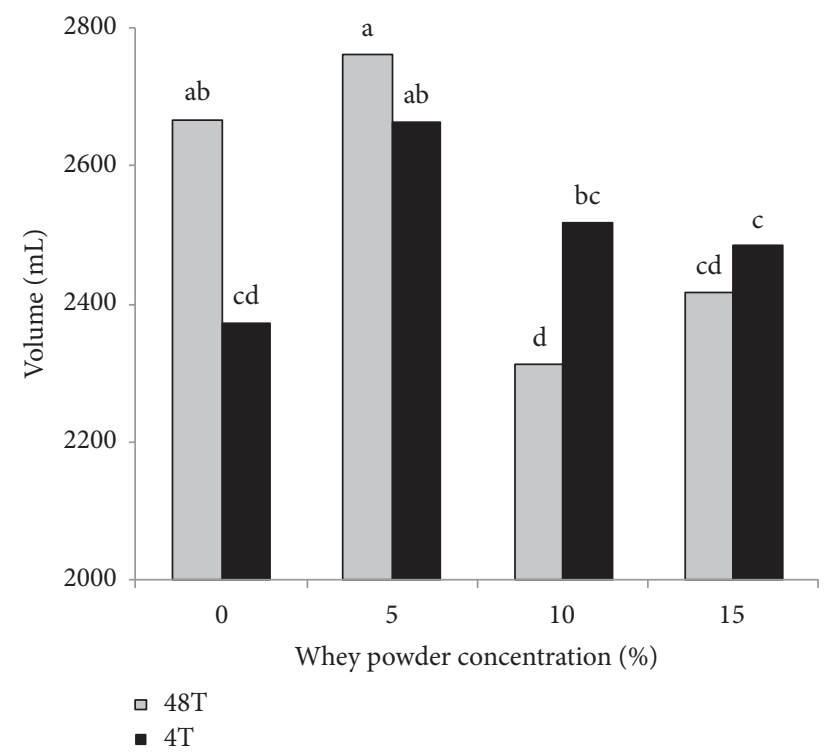

FIGURE 1: Volume of pan bread $(\mathrm{mL})$. Samples with different letters are significantly different at $p<0.05$ according to Duncan's multiple range test.

the 48TC. This was probably due to the weak gluten of the $4 \mathrm{~T}$ semolina as well as the protein content observed in the 4TC sample, which was significantly lower than that of the 48TC sample (Table 2) [20]. However, the $48 \mathrm{~T}$ bread supplemented with 10 or $15 \%$ OWP showed a significant reduction of the volume when compared to the control, while a significant opposite effect was observed in $4 \mathrm{~T}$ sample when adding $5 \%$ OWP (Figures 1 and 2). The differences in $4 \mathrm{~T}$ and $48 \mathrm{~T}$ bread volume development may be due to the different rheological properties of the dough, which are determined, in turn, by the technological characteristics of the 2 types of semolina used.

Secchi et al. [8] reported that the dough becomes firmer, stiffer, and more elastic and solid as a consequence of the OWP supplementation, thus leading to a detrimental effect on the leavening process. This could be due to its excessive strengthening effect on the gluten matrix, which showed
TABLE 3: Moisture values (\%) in bread samples after baking.

\begin{tabular}{lcc}
\hline Sample & Pan bread & Spianata bread \\
\hline 4 TC & $42.45^{\mathrm{a}}$ & $26.43^{\mathrm{a}}$ \\
$4 \mathrm{~T} 5$ & $39.83^{\mathrm{b}}$ & $27.14^{\mathrm{a}}$ \\
$4 \mathrm{~T} 10$ & $37.85^{\mathrm{c}}$ & $25.88^{\mathrm{a}}$ \\
$4 \mathrm{~T} 15$ & $37.05^{\mathrm{d}}$ & $25.43^{\mathrm{a}}$ \\
\hline $48 \mathrm{TC}$ & $41.40^{\mathrm{a}}$ & $27.17^{\mathrm{a}}$ \\
$48 \mathrm{~T} 5$ & $39.66^{\mathrm{b}}$ & $27.72^{\mathrm{a}}$ \\
$48 \mathrm{~T} 10$ & $38.61^{\mathrm{c}}$ & $26.53^{\mathrm{a}}$ \\
$48 \mathrm{~T} 15$ & $37.24^{\mathrm{d}}$ & $26.44^{\mathrm{a}}$ \\
\hline
\end{tabular}

Samples with different letters are significantly different at $p<0.05$ according to Duncan's multiple range test.

great resistance to the extension during fermentation, as also reported elsewhere [13]. Moreover, during the initial stage of baking, the gluten matrix undergoes rapid expansion, producing a sudden increase of the volume, the so-called oven spring. Thus, it can be said that the strengthening effect of the OWP on the gluten matrix hindered the oven spring in $48 \mathrm{~T}$ samples, especially at medium-high percentages of addition. On the contrary, the experimental bread obtained with the $4 \mathrm{~T}$ semolina, due to the weak gluten of the dough, benefited from the OWP fortification at least at the lowest level of supplementation. Probably, the OWP gave enough strength to increase the gas retention ability and to sustain the oven spring expansion without collapsing in 4T semolina bread (Figures 1 and 2). Crust browning index significantly increased in bread fortified with OWP with respect to the control, as expected, due to the OWP protein content that enhanced the Maillard reactions (data not shown).

3.2. Bread Staling. Moisture of bread immediately after baking $\left(\mathrm{T}_{0}\right)$ is reported in Table 3. Regardless of the differences in hydration level of the dough of both pan and Spianata bread, the moisture values after baking were different only in pan bread. This could be ascribed to the thinness of the Spianata as well as to the very high baking temperature that allows water to evaporate in a few seconds. The quality of bread was monitored for $6(0,1,2,3$, and 6$)$ and $10(0,1,2$, 3,6 , and 10) days for pan and Spianata bread, respectively. During storage, moisture did not change (data not shown), due to the packaging system. The Raman frequency of the band peaking at $\sim 480 \mathrm{~cm}^{-1}$ was used as an indicator of starch retrogradation. Its value, reported in Tables 4 and 5 for Spianata and pan bread, respectively, decreased during storage in all treatments as a consequence of the retrogradation of starch, mainly amylopectin, as explained by Piccinini et al. [11]. Those authors reported that a shift towards lower values of the band at $\sim 480 \mathrm{~cm}^{-1}$ reflects the increased crystallinity of starch, due to the progress of retrogradation.

Spianata made with $4 \mathrm{~T}$ (Table 4) evidenced a lower Raman frequency at $\mathrm{T}_{0}$ when no OWP was added, indicating a higher level of starch crystallinity in control samples; this effect was also evident at $\mathrm{T}_{1}$ and $\mathrm{T}_{2}$. The opposite effect was found at $\mathrm{T} 0, \mathrm{~T}_{1}, \mathrm{~T}_{2}$, and $\mathrm{T}_{3}$ on Spianata made with $48 \mathrm{~T}$, and 
TABLE 4: Staling of Spianata bread: data from texture analysis and Raman spectroscopy.

\begin{tabular}{|c|c|c|c|}
\hline Sample & $\begin{array}{l}\text { Storage time } \\
\text { (d) }\end{array}$ & $\begin{array}{c}\text { Distance to break } \\
(\mathrm{mm})\end{array}$ & $\begin{array}{c}\text { Raman frequency } \\
\left(\mathrm{cm}^{-1}\right)\end{array}$ \\
\hline \multirow{6}{*}{$4 \mathrm{TC}$} & 0 & $22.64^{\mathrm{aBC}}$ & $480.60^{\mathrm{aC}}$ \\
\hline & 1 & $18.96^{\mathrm{bB}}$ & $479.93^{\mathrm{bBC}}$ \\
\hline & 2 & $16.68^{\mathrm{cC}}$ & $479.45^{\mathrm{bC}}$ \\
\hline & 3 & $16.88^{\mathrm{cAC}}$ & $479.37^{\mathrm{bB}}$ \\
\hline & 6 & $14.69^{\mathrm{cdB}}$ & $479.43^{\mathrm{bNS}}$ \\
\hline & 10 & $12.38^{\mathrm{dB}}$ & $479.40^{\mathrm{bNS}}$ \\
\hline \multirow{6}{*}{$4 \mathrm{~T} 5$} & 0 & $27.45^{\mathrm{aA}}$ & $480.73^{\mathrm{aBC}}$ \\
\hline & 1 & $23.90^{\mathrm{bA}}$ & $480.40^{\mathrm{abA}}$ \\
\hline & 2 & $19.04^{\mathrm{cAB}}$ & $479.85^{\mathrm{bcB}}$ \\
\hline & 3 & $18.02^{\mathrm{cAB}}$ & $479.77^{\mathrm{bcB}}$ \\
\hline & 6 & $13.89^{\mathrm{dCD}}$ & $479.70^{c}$ \\
\hline & 10 & $14.35^{\mathrm{dA}}$ & $479.58^{\mathrm{c}}$ \\
\hline \multirow{6}{*}{$4 \mathrm{~T} 10$} & 0 & $27.06^{\mathrm{aA}}$ & $481.05^{\mathrm{aA}}$ \\
\hline & 1 & $21.60^{\mathrm{bA}}$ & $480.52^{\mathrm{bA}}$ \\
\hline & 2 & $19.51^{\mathrm{bAB}}$ & $479.76^{\mathrm{bBC}}$ \\
\hline & 3 & $19.00^{\mathrm{bA}}$ & $479.49^{\mathrm{bB}}$ \\
\hline & 6 & $16.25^{\mathrm{cA}}$ & $479.51^{\mathrm{b}}$ \\
\hline & 10 & $14.94^{\mathrm{cA}}$ & $479.34^{\mathrm{b}}$ \\
\hline \multirow{6}{*}{$4 \mathrm{~T} 15$} & 0 & $27.96^{\mathrm{aA}}$ & $480.82^{\mathrm{aB}}$ \\
\hline & 1 & $21.50^{\mathrm{bA}}$ & $480.25^{\mathrm{abAB}}$ \\
\hline & 2 & $19.01^{\mathrm{bAB}}$ & $479.68^{\mathrm{bcBC}}$ \\
\hline & 3 & $16.77^{\mathrm{cdAC}}$ & $479.47^{\mathrm{cB}}$ \\
\hline & 6 & $14.92^{\mathrm{dB}}$ & $479.40^{\mathrm{c}}$ \\
\hline & 10 & $14.38^{\mathrm{dA}}$ & $479.19^{c}$ \\
\hline \multirow{6}{*}{$48 \mathrm{TC}$} & 0 & $22.14^{\mathrm{aBC}}$ & $480.67^{\mathrm{aBC}}$ \\
\hline & 1 & $23.06^{\mathrm{aA}}$ & $480.21^{\mathrm{abAB}}$ \\
\hline & 2 & $18.28^{\mathrm{bBC}}$ & $480.14^{\mathrm{acA}}$ \\
\hline & 3 & $15.88^{\mathrm{cBC}}$ & $479.81^{\text {bdA }}$ \\
\hline & 6 & $11.22^{\mathrm{dD}}$ & $479.54^{\mathrm{cd}}$ \\
\hline & 10 & $13.21^{\mathrm{cdAB}}$ & $479.43^{\mathrm{d}}$ \\
\hline \multirow{6}{*}{$48 \mathrm{~T} 5$} & 0 & $21.52^{\mathrm{aC}}$ & $480.29^{\mathrm{aD}}$ \\
\hline & 1 & $21.68^{\mathrm{aA}}$ & $479.66^{\mathrm{bD}}$ \\
\hline & 2 & $20.93^{\mathrm{aA}}$ & $479.77^{\mathrm{bBC}}$ \\
\hline & 3 & $16.94^{\mathrm{bcAC}}$ & $479.55^{\mathrm{bB}}$ \\
\hline & 6 & $16.88^{\mathrm{bcA}}$ & $479.57^{\mathrm{b}}$ \\
\hline & 10 & $13.60^{\mathrm{cAB}}$ & $479.48^{\mathrm{b}}$ \\
\hline \multirow{6}{*}{$48 \mathrm{~T} 10$} & 0 & $25.49^{\mathrm{aAB}}$ & $480.31^{\mathrm{aD}}$ \\
\hline & 1 & $19.71^{\mathrm{bAB}}$ & $479.95^{\mathrm{bBC}}$ \\
\hline & 2 & $20.36^{\mathrm{bA}}$ & $479.90^{\mathrm{bB}}$ \\
\hline & 3 & $15.86^{\mathrm{cBC}}$ & $479.40^{\mathrm{cB}}$ \\
\hline & 6 & $13.31^{\mathrm{dCD}}$ & $479.36^{c}$ \\
\hline & 10 & $12.69^{\mathrm{dB}}$ & $479.30^{c}$ \\
\hline \multirow{6}{*}{$48 \mathrm{~T} 15$} & 0 & $21.05^{\mathrm{aC}}$ & $480.48^{\mathrm{aD}}$ \\
\hline & 1 & $15.79^{\mathrm{bC}}$ & $480.00^{\mathrm{abBC}}$ \\
\hline & 2 & $14.42^{\mathrm{bcD}}$ & $479.85^{\mathrm{acB}}$ \\
\hline & 3 & $14.03^{\mathrm{cC}}$ & $479.56^{\mathrm{bcB}}$ \\
\hline & 6 & $12.46^{\mathrm{dD}}$ & $479.44^{\mathrm{bc}}$ \\
\hline & 10 & $12.24^{\mathrm{dB}}$ & $479.24^{c}$ \\
\hline
\end{tabular}

Mean data for each column followed by different lowercased letters within each batch and capital letters within each storage time differ significantly according to Duncan's multiple range test at $p<0.05$.
TABLE 5: Staling of pan bread: data from texture analysis and Raman spectroscopy.

\begin{tabular}{|c|c|c|c|}
\hline Sample & Storage time $(\mathrm{d})$ & $\mathrm{C} 1(\mathrm{~N})$ & Raman frequency $\left(\mathrm{cm}^{-1}\right)$ \\
\hline \multirow{5}{*}{$4 \mathrm{TC}$} & 0 & $0.69^{\mathrm{dBC}}$ & $480.70^{\mathrm{aA}}$ \\
\hline & 1 & $1.59^{\mathrm{cdB}}$ & $480.07^{\mathrm{bB}}$ \\
\hline & 2 & $2.68^{\mathrm{bcB}}$ & $479.93^{\mathrm{bBC}}$ \\
\hline & 3 & $3.05^{\mathrm{bAB}}$ & $479.68^{\mathrm{bB}}$ \\
\hline & 6 & $4.17^{\mathrm{aB}}$ & $479.27^{\mathrm{cC}}$ \\
\hline \multirow{5}{*}{$4 \mathrm{~T} 5$} & 0 & $0.70^{\mathrm{dBC}}$ & $480.60^{\mathrm{aB}}$ \\
\hline & 1 & $1.40^{\mathrm{cBC}}$ & $480.10^{\mathrm{bB}}$ \\
\hline & 2 & $2.53^{\mathrm{bB}}$ & $479.80^{\mathrm{bBC}}$ \\
\hline & 3 & $2.83^{\mathrm{bB}}$ & $479.53^{\mathrm{cB}}$ \\
\hline & 6 & $4.35^{\mathrm{aAB}}$ & $479.58^{\mathrm{cB}}$ \\
\hline \multirow{5}{*}{$4 \mathrm{~T} 10$} & 0 & $0.65^{\mathrm{eBC}}$ & $480.59^{\mathrm{aB}}$ \\
\hline & 1 & $1.57^{\mathrm{dB}}$ & $480.05^{\mathrm{bB}}$ \\
\hline & 2 & $2.54^{\mathrm{cB}}$ & $480.07^{\mathrm{bB}}$ \\
\hline & 3 & $3.11^{\mathrm{bAB}}$ & $479.56^{\mathrm{cB}}$ \\
\hline & 6 & $4.61^{\mathrm{aA}}$ & $479.32^{\mathrm{cC}}$ \\
\hline \multirow{5}{*}{$4 \mathrm{~T} 15$} & 0 & $0.84^{\mathrm{dB}}$ & $480.72^{\mathrm{aA}}$ \\
\hline & 1 & $1.91^{\mathrm{cAB}}$ & $480.14^{\mathrm{bB}}$ \\
\hline & 2 & $2.41^{\mathrm{bB}}$ & $479.98^{\mathrm{bcB}}$ \\
\hline & 3 & $2.74^{\mathrm{abB}}$ & $479.57^{\mathrm{cB}}$ \\
\hline & 6 & $3.71^{\mathrm{aC}}$ & $479.57^{\mathrm{cB}}$ \\
\hline \multirow{5}{*}{$48 \mathrm{TC}$} & 0 & $0.90^{\mathrm{dB}}$ & $480.80^{\mathrm{aA}}$ \\
\hline & 1 & $1.34^{\mathrm{cBC}}$ & $480.47^{\mathrm{aA}}$ \\
\hline & 2 & $1.63^{\mathrm{bD}}$ & $480.27^{\mathrm{bA}}$ \\
\hline & 3 & $1.76^{\mathrm{bD}}$ & $480.02^{\mathrm{bA}}$ \\
\hline & 6 & $2.80^{\mathrm{aE}}$ & $480.05^{\mathrm{bA}}$ \\
\hline \multirow{5}{*}{$48 \mathrm{~T} 5$} & 0 & $0.88^{\mathrm{dB}}$ & $480.57^{\mathrm{aB}}$ \\
\hline & 1 & $1.40^{\mathrm{cBC}}$ & $479.64^{\mathrm{bC}}$ \\
\hline & 2 & $2.12^{\mathrm{bC}}$ & $479.66^{\mathrm{bC}}$ \\
\hline & 3 & $2.18^{\mathrm{bC}}$ & $479.69^{\mathrm{bB}}$ \\
\hline & 6 & $3.05^{\mathrm{aD}}$ & $479.61^{\mathrm{bB}}$ \\
\hline \multirow{5}{*}{$48 \mathrm{~T} 10$} & 0 & $1.33^{\mathrm{dA}}$ & $480.61^{\mathrm{aB}}$ \\
\hline & 1 & $2.51^{\mathrm{cA}}$ & $480.25^{\mathrm{bcAB}}$ \\
\hline & 2 & $2.68^{\mathrm{cB}}$ & $479.81^{\mathrm{bcBC}}$ \\
\hline & 3 & $3.41^{\mathrm{bA}}$ & $479.25^{\mathrm{cC}}$ \\
\hline & 6 & $4.67^{\mathrm{aA}}$ & $479.27^{\mathrm{cC}}$ \\
\hline \multirow{5}{*}{$48 \mathrm{~T} 15$} & 0 & $1.00^{\mathrm{dAB}}$ & $480.52^{\mathrm{aB}}$ \\
\hline & 1 & $2.78^{\mathrm{cA}}$ & $480.07^{\mathrm{abB}}$ \\
\hline & 2 & $3.37^{\mathrm{bA}}$ & $479.65^{\mathrm{bcC}}$ \\
\hline & 3 & $3.83^{\mathrm{bA}}$ & $479.61^{\mathrm{bcB}}$ \\
\hline & 6 & $4.71^{\mathrm{aA}}$ & $479.22^{\mathrm{cC}}$ \\
\hline
\end{tabular}

Mean data for each column followed by different lowercased letters within each batch and capital letters within each storage time differ significantly according to Duncan's multiple range test at $p<0.05$.

thus the control showed a lower level of starch crystallinity than the OWP supplemented counterparts.

The addition of OWP had an improving effect on texture of $4 \mathrm{~T}$ Spianata samples, as values of the distance to break increased at $\mathrm{T}_{0}, \mathrm{~T}_{1}$, and $\mathrm{T}_{2}$ times, with respect to control (Table 4). Results obtained on Spianata bread suggest that the 


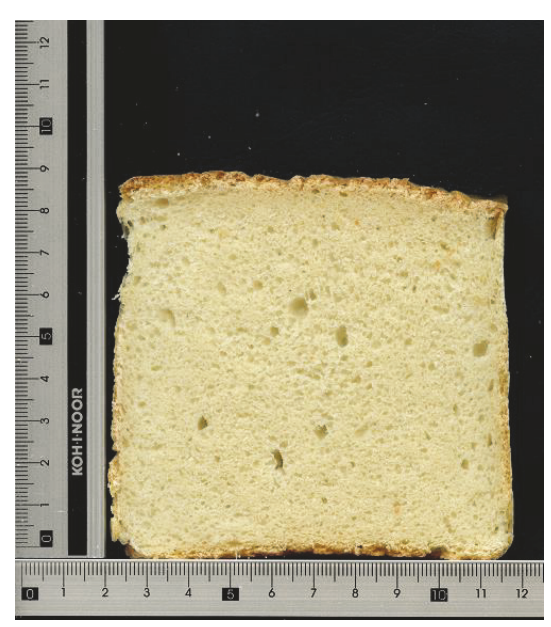

(a)

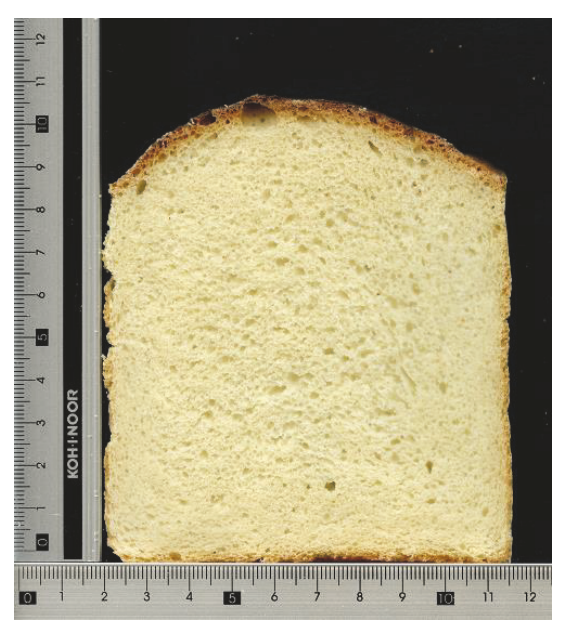

(b)

FIgure 2: Pan bread sections: (a) 4TC and (b) 4 T5.

intrinsic extensibility properties of Senatore Cappelli variety have been enhanced by the addition of OWP, since a higher distance to break means increased extensibility. In a previous study, Secchi et al. [21] reported that when the distance to break falls below the value of $18 \mathrm{~mm}$, the bread was refused by consumers, because it was no more "rollable" without breaking. For this reason, on the basis of the data obtained in this study, it can be said that the addition of OWP improved the time of acceptability up to 3 days in $4 \mathrm{~T} 5$ and 4T10, and up to 2 days in the $4 \mathrm{~T} 15$ sample, while it was only 1 day in 4TC.

No beneficial effect was observed, instead, in the extensibility of $48 \mathrm{~T}$ samples supplemented with OWP. In particular, the $48 \mathrm{~T} 15$ evidenced a distance-to-break value significantly lower than the control during the first 2 days of storage. In fact, the distance-to-break values were lower than $18 \mathrm{~mm}$ after the second day of storage in all the experimental samples, except the $48 \mathrm{~T} 15$ bread in which this limit value was reached after only 1 day.

As reported in Table 4, data from Raman spectroscopy and texture analyzer showed reciprocal accordance.

In fact, a lower value of distance to break was found in the samples in which the peak frequency shifted towards lower wave numbers, indicating that the level of starch retrogradation affects the extensibility of Spianata.

Values of Maxwell modulus $C_{1}$ and Raman frequency in pan bread stored over 6 days in modified atmosphere are reported in Table 5. The OWP addition had no effect on staling of 4T samples, while it led to significantly lower values of Raman frequency in 48T bread, which is a higher level of starch retrogradation. Raman data were also confirmed by the texture analysis. In fact, $C 1$ values of $48 \mathrm{~T}$ supplemented with OWP were significantly higher than the control, thus indicating a more elastic and firmer crumb. In particular, the $48 \mathrm{~T} 10$ and $48 \mathrm{~T} 15$ samples showed an important increase at $\mathrm{T}_{1}$, if compared to control, while at $\mathrm{T}_{2}$ significance was found also for $48 \mathrm{TC}$. The magnitude of $C_{i}$ can be taken as a measure of the elasticity and firmness of the crumb, which increase over storage due to the staling phenomenon. Also, in this case, data were consistent with those from Raman analyses, which showed a lower Raman frequency corresponding to a higher level of retrogradation in $48 \mathrm{~T}$ samples. This again confirms the key role of starch crystalline status in the quality of bread. It is important to highlight how the addition of OWP had a detrimental effect on the quality of the $48 \mathrm{~T}$ samples, which showed a higher level of starch retrogradation accompanied by increased crumb firmness.

The $48 \mathrm{~T}$ semolina is characterized by having a higher protein content than the $4 \mathrm{~T}$, which probably resulted in a competition between OWP and semolina proteins of $48 \mathrm{~T}$, thus explaining the results obtained.

The correlation between the evolution of the crumb hardness and the Raman frequency over storage in semolinabased pan bread has been already reported and confirmed our results [11].

3.3. Image Analysis of Bread Crumb. The image analysis of pan bread crumb was performed to compare the cell sizes of the experimental samples. Results are reported in Figure 3, where $x$ (area of a cell in $\mathrm{mm}^{2}$ ) and $y$ (the complementary cumulative distribution function) were plotted on a log-log scale. Data of the areas and the numbers of the gas cells were used to calculate the complementary cumulative distribution function (CCDF), as fully described by Fois et al. [13]. In summary, the CCDF $=1-\mathrm{CDF}$ (cumulative distribution function) is the integral of the probability distribution function of the areas.

The analysis of $4 \mathrm{~T}$ samples (Figure 3(a)) highlighted that the curves of samples 4TC, 4T10, and 4T15 almost completely overlap. The curve of the $4 \mathrm{~T} 5$ overlapped with the other curves only in the first part, that is, the small size cells, while in all the remaining parts, which accounted for medium to large cell size, the 4T5 curve was clearly above the other ones. This indicates that $4 \mathrm{~T} 5$ differed from all the other samples in the cell size distribution, in agreement with the data registered for the bread volume previously reported (Figure 1). The addition of $5 \%$ of OWP had also 


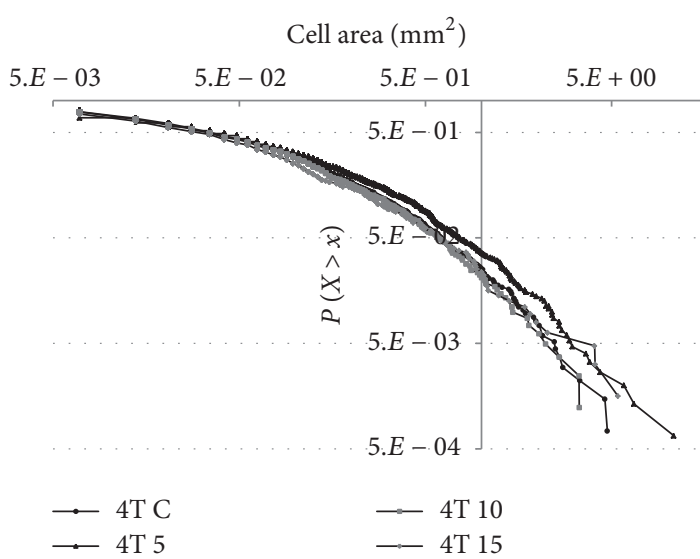

(a)

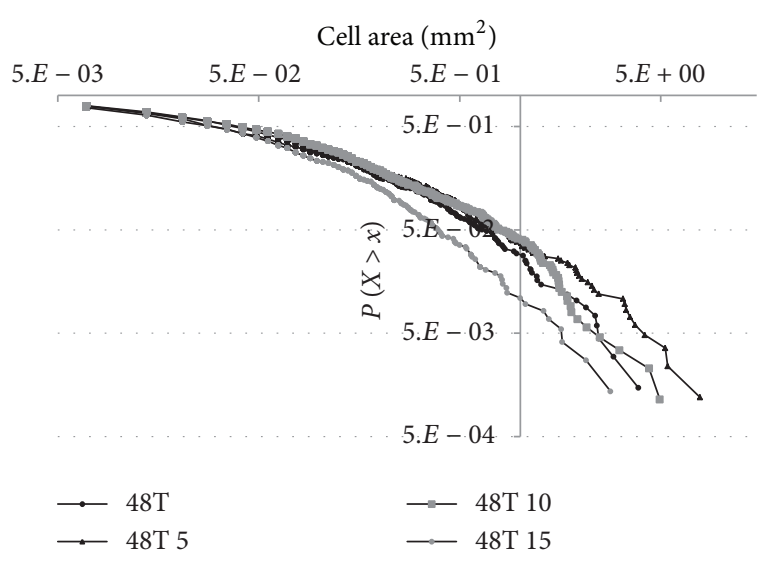

(b)

FIgURE 3: Complementary cumulative density function analysis in pan bread crumb made with semolina 4T (a) and semolina 48T (b).

a different effect on the cell size distribution of $48 \mathrm{~T}$, with some differences. In fact, the 4T5 and 48T5 curves overlapped with their controls (4TC and 48TC), with the difference that 4TC and 4T5 overlapped only in the first part, while 48TC and 48T5 overlapped for a greater range of $x$ values and differed mainly for the biggest cell sizes, that is, the tail of the curve. The 4TC and 48TC curves remained well below their correspondent $4 \mathrm{~T} 5$ and $48 \mathrm{~T} 5$ curves, but $4 \mathrm{TC}$ showed a lower probability of finding medium and large cell sizes with respect to the $4 \mathrm{~T} 5$ while $48 \mathrm{TC}$ evidenced larger cell sizes than $48 \mathrm{~T} 5$.

This means that the addition of 5\% of OWP improved the crumb structure in both $4 \mathrm{~T}$ and $48 \mathrm{~T}$, as demonstrated by the volume of pan bread.

The addition of OWP had a detrimental effect on the cell size distribution in the $48 \mathrm{~T} 15$ sample. In fact, the $48 \mathrm{~T} 15$ curve did not overlap with the other curves, and thus the probability $(y)$ of finding a cell size greater than a given $x$ value was lower than in the control (Figure 3(b)). From a technological point of view, this means that the $48 \mathrm{~T} 15$ sample showed a more dense and compact crumb structure, with a low probability of finding medium and great cell size. These data are in agreement with the volume of the 48T15 bread, which was significantly lower than 48TC and 48T5 (Figure 1).

3.4. Sensory Analysis. CATA test (Check All That Apply) [22], a recent novel methodology, was performed to obtain rapid profiles of the eight pan bread samples produced. Moreover, a judgment of overall liking and intention to purchase, expressed by the consumers to evaluate the acceptance, was added to the CATA results. Cochran's $Q$ test highlighted significant differences among the pan bread samples for 11 out of 18 attributes. The attributes were as follows: good to accompany, smell of dairy products, dry, soft in the mouth, nice colour, soft to touch, sweet, springy to touch, smell of traditional bread, rubbery, and ideal for breakfast. The 4T5 sample was reported to be less rubbery and dry and softer to touch, of nice colour, softer, and good to accompany

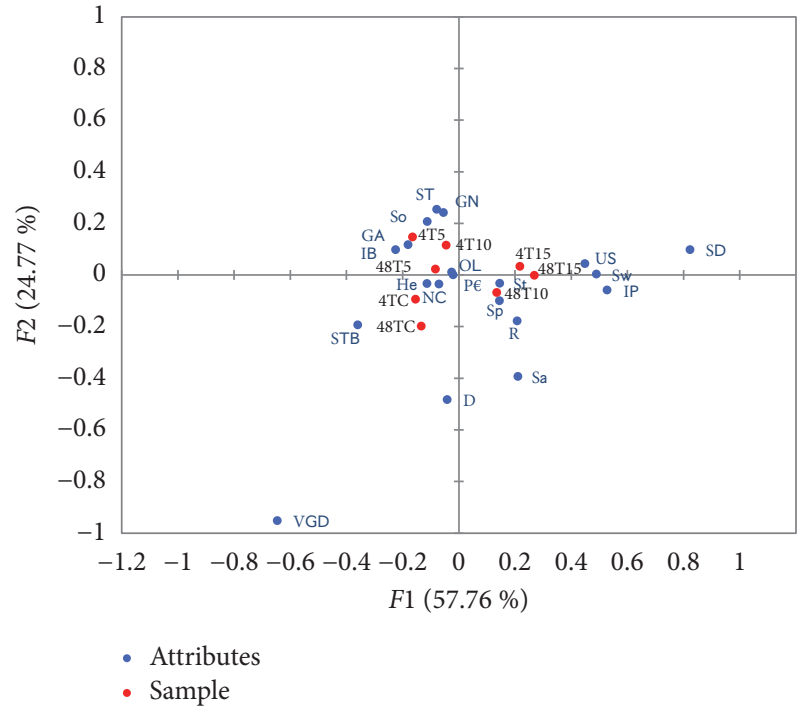

FIGURE 4: Principal component analysis of bread attributes. S: sticky; GA: good to accompany; SD: smell of dairy products; VGD: very good for diet; US: unpleasant smell; Sa: salty; D: dry; So: soft; NC: nice colour; ST: soft to touch; H: healthy, IP: innovative product; Sw: sweet; Sp: springy to touch; GN: good for nutrition; STB: smell of traditional bread; R: rubbery; IB: ideal for breakfast; P€: propensity to purchase; OL: overall liking.

than the other samples. Correspondence analysis (Figure 4) confirmed this behaviour, since the OWP samples were distributed along the $\mathrm{PCl}$ and were described by the following attributes: unpleasant smell, smell of dairy products, sticky, spring to touch, rubbery, and sweet, while the $4 \mathrm{~T} 5$ sample was differentiated from the PC2, confirming the results obtained from Cochran's $Q$ test.

Consumer overall liking and propensity to purchase data revealed that the $4 \mathrm{~T} 5$ sample was the most preferred, reaching the highest score (5.33 on a scale from 0 to 9 ). This result confirms what is reported in the literature [23], where 
TABLE 6: Pearson's correlation between textural data and CATA attributes.

\begin{tabular}{|c|c|c|c|c|c|c|}
\hline \multirow{2}{*}{ Attributes } & \multirow{2}{*}{ Moisture } & \multicolumn{4}{|c|}{ Crust pan bread colour indexes } & \multirow{2}{*}{$F \max (\mathrm{N})$} \\
\hline & & $L$ & $a$ & B & Browning index & \\
\hline Overall liking & 0.176 & -0.012 & 0.380 & 0.057 & 0.012 & -0.502 \\
\hline Sticky & -0.522 & -0.270 & -0.052 & -0.239 & 0.270 & 0.234 \\
\hline Good to accompany & 0.196 & -0.007 & 0.353 & 0.085 & 0.007 & -0.549 \\
\hline Smell of dairy products & $-0.882^{*}$ & $-0.772^{*}$ & -0.504 & $-0.799^{*}$ & $0.772^{*}$ & 0.429 \\
\hline Very good for diet & $0.827^{*}$ & $0.765^{*}$ & 0.407 & $0.738^{*}$ & $-0.765^{*}$ & 0.172 \\
\hline Unpleasant smell & $-0.788^{*}$ & $-0.727^{*}$ & -0.572 & $-0.728^{*}$ & $0.727^{*}$ & 0.295 \\
\hline Salty & 0.072 & 0.276 & 0.335 & 0.305 & -0.276 & $0.838^{*}$ \\
\hline Dry & 0.597 & 0.673 & -0.021 & 0.544 & -0.673 & 0.155 \\
\hline Soft & 0.036 & -0.235 & -0.057 & -0.228 & 0.235 & -0.686 \\
\hline Nice colour & 0.392 & 0.284 & $0.781^{*}$ & 0.395 & -0.284 & 0.047 \\
\hline Soft to touch & -0.122 & -0.361 & -0.113 & -0.331 & 0.361 & $-0.722^{*}$ \\
\hline Healthy & 0.480 & 0.479 & 0.557 & 0.451 & -0.479 & 0.016 \\
\hline Innovative product & -0.455 & -0.251 & -0.135 & -0.350 & 0.251 & 0.527 \\
\hline Sweet & $-0.771^{*}$ & -0.655 & -0.552 & $-0.720^{*}$ & 0.655 & 0.336 \\
\hline Springy to touch & -0.377 & -0.221 & 0.279 & -0.108 & 0.221 & $0.817^{*}$ \\
\hline Good for nutrition & -0.284 & -0.460 & -0.378 & -0.422 & 0.460 & $-0.854^{*}$ \\
\hline Smell of traditional bread & $0.846^{*}$ & $0.725^{*}$ & 0.691 & $0.791^{*}$ & $-0.725^{*}$ & -0.109 \\
\hline Rubbery & -0.399 & -0.162 & -0.121 & -0.168 & 0.162 & $0.775^{*}$ \\
\hline Ideal for breakfast & 0.306 & 0.251 & 0.569 & 0.312 & -0.251 & -0.396 \\
\hline Propensity to purchase & 0.152 & -0.043 & 0.313 & 0.036 & 0.043 & -0.587 \\
\hline
\end{tabular}

${ }^{*}$ Significant correlations according to Pearson's correlation are reported in bold $(p<0.05)$.

softness and crumb colour represent the most desired sensory properties for gluten-free bread.

Pearson's correlation between texture data and sensory analysis showed that the texture parameter Fmax was positively correlated with rubbery and sticky, while it was negatively correlated with good for nutrition and salty (Table 6). It has to be considered that hardness is a very important sensory characteristic when assessing bread quality [24]. In this case, harder bread resulted in a more rubbery and sticky texture perceived. With regard to the colour, crust browning index was positively correlated with smell of dairy products and unpleasant smell, which are considered unwanted qualities for bread products, contrary to the fact that brown pigment formation is desirable during bread making due to the Maillard reaction [25]. In this case, the presence of ovine whey increased the formation of brown pigments but, at the same time, increased the perceived sensation of dairy products. No correlation was found between the crumb colour and the sensory descriptors. Furthermore, high values of moisture were positively correlated with smell of traditional bread and very good for diet; on the contrary, low values of moisture were correlated with negatives attributes such as unpleasant smell and smell of dairy products. Hence, as expected, overall liking was positively correlated with the propensity to purchase and negatively correlated with undesirable descriptors such as rubbery, dry, unpleasant smell, smell of dairy products, and sticky, confirming what is reported in the literature on the sensory descriptors, which drive consumer preference [23].

\section{Conclusions}

The use of OWP in bread making had different effects on bread, depending on the quality of the raw material, the type of bread produced, and the amount of OWP added. As expected, among the two types of semolina, the one with weak gluten $(4 \mathrm{~T})$ produced bread with a lower volume than that obtained using the other type with strong and tenacious gluten (48T). The addition of OWP led to a strengthening effect on the gluten matrix of both, with a positive effect on the volume of $4 \mathrm{~T}$ pan bread, but a negative effect on $48 \mathrm{~T}$ samples,. Therefore, the volume of pan bread in $4 \mathrm{~T}$ sample was higher with the addition of a low percentage of OWP (5\%), while it was not affected by the addition of higher concentrations of OWP (10 and 15\%). On the contrary, in $48 \mathrm{~T}$ samples, the addition of OWP had a detrimental effect on bread volume at all supplementation levels. To our knowledge, this is the first paper describing a positive effect of whey protein on bread volume; other authors reported a negative effect both in crumb bread $[6,26]$ and in flat bread [27]. The addition of OWP improved the textural characteristics of Spianata produced with $4 \mathrm{~T}$ [28]. In fact, starch retrogradation was depressed and extensibility of Spianata was improved. Crumb characteristics, measured in terms of cell size distribution, were also improved with $5 \%$ of OWP in both $4 \mathrm{~T}$ and $48 \mathrm{~T}$, but the effect on bread volume was particularly evident only in $4 \mathrm{~T}$.

Finally, bread produced using $4 \mathrm{~T}$ and 5\% of OWP was the most preferred sample by consumers. This study 
demonstrates that the use of OWP, at certain percentage, can improve the quality of bread, when using semolina with weak gluten.

\section{Conflicts of Interest}

The authors declare that they have no conflicts of interest.

\section{Acknowledgments}

This work was carried out with the financial support of Sardegna Ricerche (TOP-DOWN program), Project Title "SIOPROFO."

\section{References}

[1] C. Fadda, E. M. Santos, A. Piga, and C. Collar, "Innovative traditional Italian durum wheat breads: Influence of yeast and gluten on performance of sourdough Moddizzosu breads," Cereal Chemistry, vol. 87, no. 3, pp. 204-213, 2010.

[2] H. Goesaert, K. Brijs, W. S. Veraverbeke, C. M. Courtin, K. Gebruers, and J. A. Delcour, "Wheat flour constituents: how they impact bread quality, and how to impact their functionality," Trends in Food Science \& Technology, vol. 16, no. 1-3, pp. 12-30, 2005.

[3] C. Collar, P. Conte, C. Fadda, and A. Piga, "Gluten-free doughmaking of specialty breads: Significance of blended starches, flours and additives on dough behaviour," Food Science and Technology International, vol. 21, no. 7, pp. 523-536, 2015.

[4] J. G. Zadow, "Whey and whey powders," in Encyclopedia of food science food technologies and nutrition, R. Macrae, R. K. Robinson, and M. J. Sadler, Eds., pp. 4888-4895, Academic Press Inc, San Diego Ca, 1993.

[5] N. Erdogdu-Arnoczky, Z. Czuchajowska, and Y. Pomeranz, "Functionality of whey and casein in fermentation and in breadbaking by fixed and optimized procedures," Cereal Chemistry, vol. 73, no. 3, pp. 309-316, 1996.

[6] C. Kadharmestan, B.-K. Baik, and Z. Czuchajowska, "Whey protein concentrate treated with heat or high hydrostatic pressure in wheat-based products," Cereal Chemistry, vol. 75, no. 5, pp. 762-766, 1998.

[7] AACC Approved Methods of the American Association of Cereal Chemists, $10^{\text {th }}$ edn. Methods 08-12, 10-05, 38-12A, 44-16, 46-12, 54-30A, 54-50. St. Paul, MN: The American Association of Cereal Chemists. (2000).

[8] N. Secchi, C. Fadda, M. Piccinini et al., "The Effects of Ovine Whey Powders on Durum Wheat-Based Doughs," Journal of Food Quality, vol. 2018, pp. 1-8, 2018.

[9] P. Vinci, S. Fois, E. Parente, T. Roggio, and P. Catzeddu, "A study on relationships between durum wheat semolina properties, technological mixing parameters and the properties of dough after mixing," International Journal of Food Science \& Technology, vol. 48, no. 12, pp. 2541-2550, 2013.

[10] M. Campus, M. F. Addis, R. Cappuccinelli et al., "Stress relaxation behaviour and structural changes of muscle tissues from Gilthead Sea Bream (Sparus aurata L.) following high pressure treatment," Journal of Food Engineering, vol. 96, no. 2, pp. 192-198, 2010.

[11] M. Piccinini, S. Fois, N. Secchi, M. Sanna, T. Roggio, and P. Catzeddu, "The Application of NIR FT-Raman Spectroscopy to Monitor Starch Retrogradation and Crumb Firmness in Semolina Bread," Food Analytical Methods, vol. 5, no. 5, pp. 1145-1149, 2012.

[12] J. A. Gray and J. N. Bemiller, "Bread staling: Molecular basis and control," Comprehensive Reviews in Food Science and Food Safety, vol. 2, no. 1, pp. 1-21, 2003.

[13] S. Fois, C. Fadda, R. Tonelli et al., "Effects of the fermentation process on gas-cell size two-dimensional distribution and rheological characteristics of durum-wheat-based doughs," Food Research International, vol. 49, no. 1, pp. 193-200, 2012.

[14] H. J. MacFie, N. Bratchell, K. Greenhoff, and L. V. Vallis, "Designs to balance the effect of order of presentation and firstorder carry-over effects in hall tests," Journal of Sensory Studies, vol. 4, no. 2, pp. 129-148, 1989.

[15] G. Ares, F. Reis, D. Oliveira et al., "Recommendations for use of balanced presentation order of terms in CATA questions," Food Quality and Preference, vol. 46, pp. 137-141, 2015.

[16] M. A. Giménez, A. Gámbaro, M. Miraballes et al., "Sensory evaluation and acceptability of gluten-free Andean corn spaghetti," Journal of the Science of Food and Agriculture, vol. 95, no. 1, pp. 186-192, 2015.

[17] F. J. Comendador, "Il pane e altri prodotti da forno in. Societ $\alpha$ Italiana di Scienze Sensoriali, Atlante sensoriale dei prodotti alimentari, Tecniche Nuove," in. Società Italiana di Scienze Sensoriali, pp. 156-176, 2012.

[18] C. E. Lupano, "Gelation of mixed systems whey protein concentrate-gluten in acidic conditions," Food Research International, vol. 33, no. 8, pp. 691-696, 2000.

[19] J. G. Zadow, "Whey utilization," in Whey and Lactose Processing, Springer Netherlands, Dordrecht, 1992.

[20] H. Wieser and R. Kieffer, "Correlations of the amount of gluten protein types to the technological properties of wheat flours determined on a micro-scale," Journal of Cereal Science, vol. 34, no. 1, pp. 19-27, 2001.

[21] N. Secchi, G. Stara G, P. P. Piu, P. Catzeddu, and T. Roggio T, "Studio per la determinazione del tempo di alta qualità del pane spianata," Tecnica Molitoria, vol. 1, pp. 22-27, 2008.

[22] P. Varela and G. Ares, "Sensory profiling, the blurred line between sensory and consumer science. A review of novel methods for product characterization," Food Research International, vol. 48, no. 2, pp. 893-908, 2012.

[23] E. C. Morais, A. G. Cruz, J. A. F. Faria, and H. M. A. Bolini, "Prebiotic gluten-free bread: Sensory profiling and drivers of liking," LWT-Food Science and Technology, vol. 55, no. 1, pp. 248-254, 2014.

[24] M. E. Matos and C. M. Rosell, "Quality Indicators of RiceBased Gluten-Free Bread-Like Products: Relationships Between Dough Rheology and Quality Characteristics," Food and Bioprocess Technology, vol. 6, no. 9, pp. 2331-2341, 2013.

[25] A. Ramírez-Jiménez, E. Guerra-Hernández, and B. GarcíaVillanova, "Browning indicators in bread," Journal of Agricultural and Food Chemistry, vol. 48, no. 9, pp. 4176-4181, 2000.

[26] S. Kenny, K. Wehrle, C. Stanton, and E. K. Arendt, "Incorporation of dairy ingredients into wheat bread: Effects on dough rheology and bread quality," European Food Research and Technology, vol. 210, no. 6, pp. 391-396, 2000.

[27] D. Indrani, P. Prabhasankar, J. Rajiv, and G. V. Rao, "Influence of whey protein concentrate on the rheological characteristics of dough, microstructure and quality of unleavened flat bread (parotta)," Food Research International, vol. 40, no. 10, pp. 12541260, 2007. 
[28] N. Secchi, The ability of ovine whey powder to improve quality of Sardinian bakery products, 2018, http://eprints.uniss.it/11649/1/ Secchi_N_The_ability_of_ovine.pdf. 


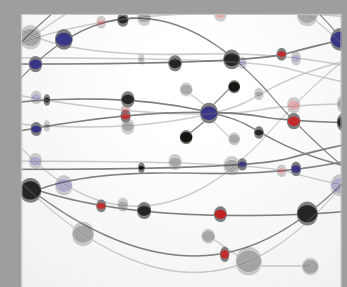

The Scientific World Journal
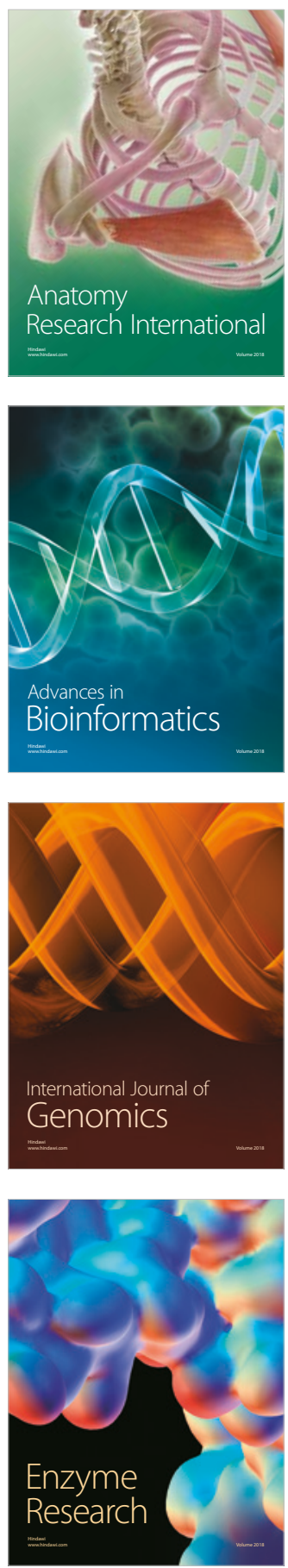
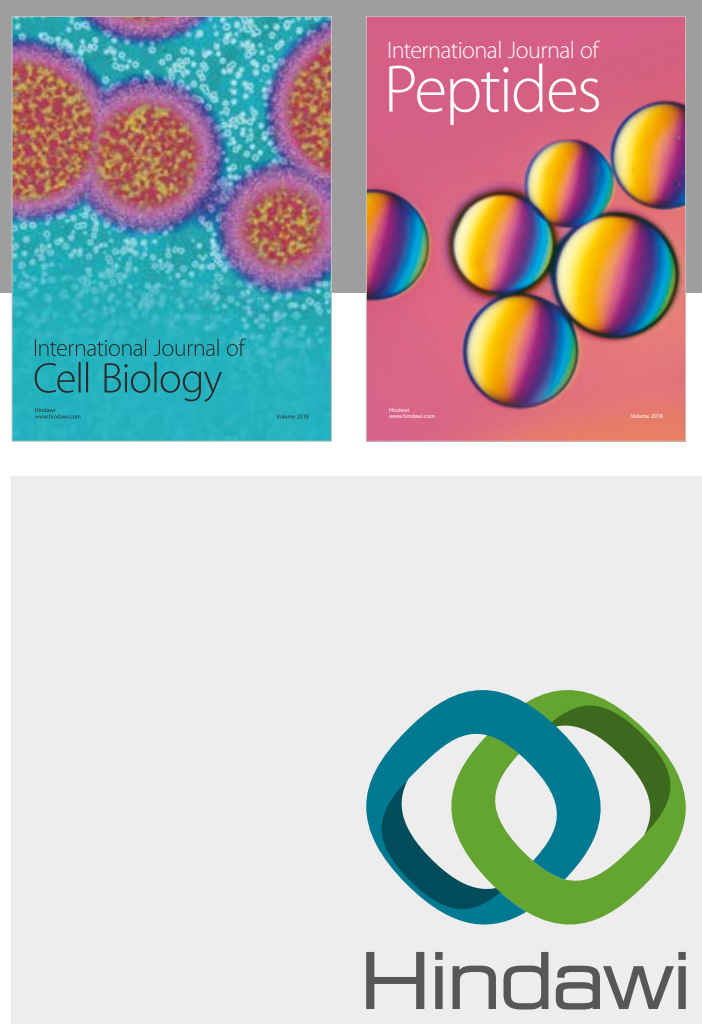

Submit your manuscripts at

www.hindawi.com
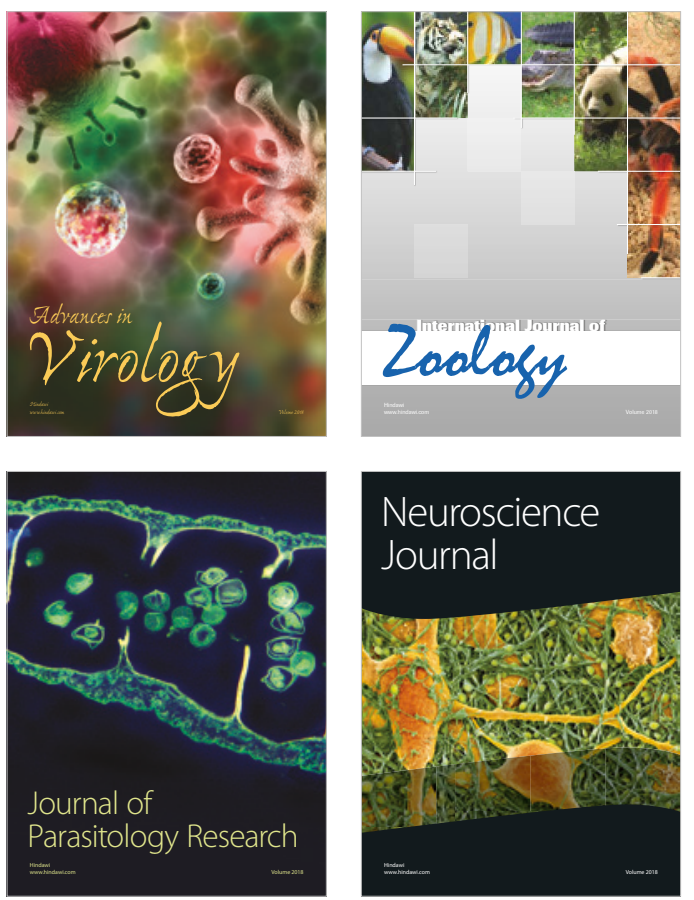
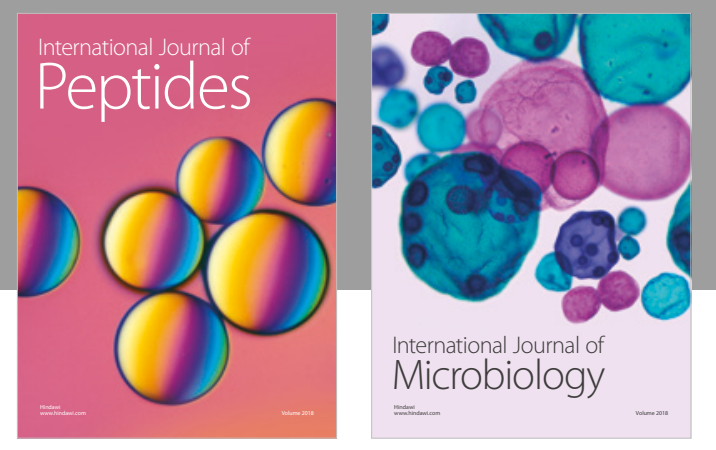

nternational Journal of Microbiology
Journal of
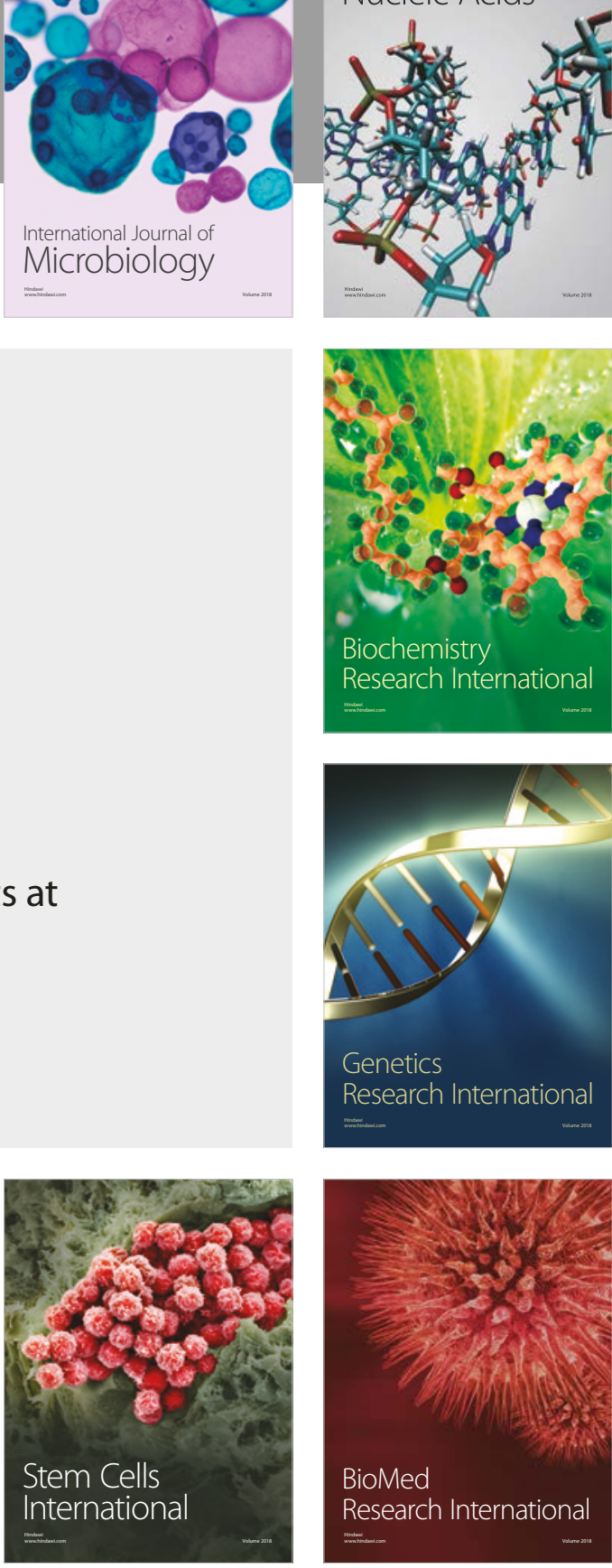
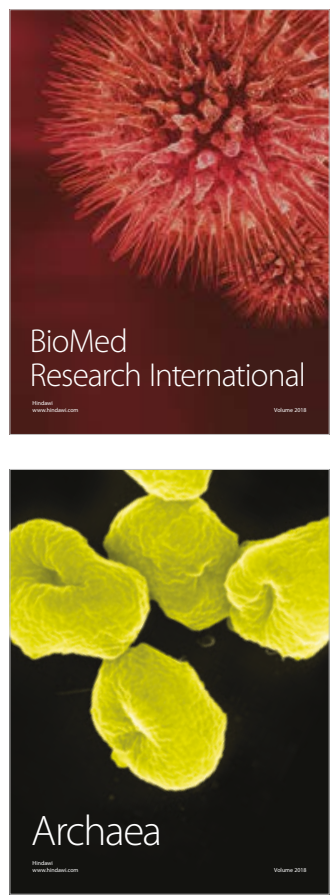